\title{
ЗМІНИ ПОКАЗНИКІВ ПРОТЕОЛІТИЧНОЇ АКТИВНОСТІ СИРОВАТКИ КРОВІ У ЩУРІВ ЗА УМОВИ ПАСИВНОГО ТЮТЮНОКУРІННЯ НА ТЛІ ТРИВАЛОГО ВВЕДЕННЯ НАТРІЙ ГЛУТАМАТУ У ВІКОВОМУ АСПЕКТІ
}

Вступ. Тютюнокуріння щорічно вбиває понад 8 млн осіб у всьому світі, з них близько 1,2 млн є пасивними курцями. Характерна ознака сучасних харчових технологій - використання харчових добавок, які не завжди безпечні для здоров'я людини.

Мета дослідження - вивчити вплив пасивного тютюнокуріння на тлі тривалого введення натрій глутамату на показники протеолітичної активності сироватки крові в щурів різного віку.

Методи дослідження. Досліди виконано на 32-х безпородних статевозрілих білих щурах-самцях масою 180-200 г та 32-х безпородних статевонезрілих білих щурах-самцях масою 60-80 г. Тварин поділили на 4 групи: 1-ша - контроль; 2-га - щури, яким моделювали пасивне тютюнокуріння; 3-тя - щури, яким вводили натрій глутамат; 4-та - щури, яким моделювали пасивне тютюнокуріння на тлі введення натрій глутамату. Загальну протеолітичну активність сироватки крові визначали, використовуючи азосубстрати (азоальбумін, азоказеїн та азоколаген) фрірми "Simko Ltd" (Україна) відповідно до інструкції виробника.

Результати й обговорення. За умови пасивного тютюнокуріння в сироватці крові статевозрілих щурів збільшувалась кількість продуктів розпаду азоальбуміну, азоказеїну та азоколагену (на 59,8 \% ( $p=0,002), 38,3$ \% ( $p<0,001), 32,6$ \% ( $p=0,005)$ відповідно), що свідчило про підвищену деградацію як високомолекулярних, так і низькомолекулярних протеїнів та колагену. Пасивне тютюнокуріння на тлі застосування натрій глутамату при цьому не викликало вірогідних змін відносно ізольованої дії тютюнового диму. В сироватці крові статевонезрілих щурів пасивне тютюнокуріння на тлі застосування натрій глутамату зумовлювало вірогідні зміни лізису азоальбуміну, який перевищував дані за умови ізольованого впливу тютюнового диму на 40,9% (p=0,002), і лізису азоказеїну, що перевищував дані при ізольованому впливі тютюнового диму на 36,5 \% (p=0,003). У віковому аспекті інтенсивність змін лізису азоальбуміну, азоказеїну та азоколу при пасивному тютюнокурінні на тлі введення натрій глутамату переважала на 31,38 і 12,7 \% відповідно у статевонезрілих щурів.

Висновок. Отримані результати свідчать про вищу інтенсивність протеолітичних процесів у крові статевонезрілих щурів порівняно зі статевозрілими. Імовірно, це зумовлено вищою інтенсивністю утворення вільних радикалів, меншою швидкістю їх знешкодження та утворенням більшої кількості окисномодифрікованих протеїнів.

КЛЮЧОВІ СЛОВА: пасивне тютюнокуріння; натрій глутамат; протеолітична активність.

ВСТУП. За оцінками Всесвітньої організації охорони здоров'я, тютюнокуріння щорічно вбиває понад 8 млн чоловік у всьому світі, з них близько 1,2 млн є пасивними курцями [1]. В Європейському регіоні майже 0,7 млн смертей на рік пов'язані з уживанням тютюну [2]. В Україні в результаті куріння щорічно вмирає близько 120 тис. осіб [3].

Важливими критеріями є ранній вік початку куріння та висока його поширеність серед дітей і підлітків. Поширеність тютюнокуріння серед європейських підлітків висока, причому в деяких країнах (Чехія, Латвія, Литва) рівні поширеності (с) Н. В. Гецько, І. Я. Криницька, 2020. куріння серед молоді практично збігаються 3 рівнями куріння серед дорослих [4, 5]. За результатами дослідження поведінки дітей шкільного віку відносно здоров'я (HBSC) за 2013-2014 рр., частка хлопчиків віком 15 років, які курять хоча б один раз на тиждень, коливалась у діапазоні від 5 \% у Вірменії до 51 \% у Гренландії, частка дівчаток віком 15 років - відповідно, від 1 \% у Вірменії до 53 \% у Гренландії. Середній показник по всіх країнах, представлених у доповіді, становив $12 \%$ для хлопчиків і $11 \%$ для дівчаток [6]. Нікотин, що входить до складу тютюну, викликає сильну залежність, особливо в дітей, організм яких перебуває в процесі росту і розвитку та 
особливо чутливий до негативного впливу різних фракторів, у тому числі й до впливу тютюну [7].

Водночас характерною ознакою сучасних харчових технологій $є$ використання харчових добавок, які виконують технологічні фрункції, поліпшують органолептичні властивості харчових продуктів і не завжди є безпечними для здоров'я людини [8]. Однією з найпоширеніших харчових добавок як в Україні, так і в Європі $€$ натрій глутамат $[9,10]$. Реальна загроза одночасного надходження в організм тютюнового диму і натрій глутамату надає вивченню їх поєднаної дії особливої актуальності.

Мета дослідження - вивчити вплив пасивного тютюнокуріння на тлі тривалого введення натрій глутамату на показники протеолітичної активності сироватки крові в щурів різного віку.

МЕТОДИ ДОСЛІДЖЕННЯ. ДОсліДИ ВИКонаНО на 32-х безпородних статевозрілих білих щурах-самцях масою 180-200 г та 32-х безпородних статевонезрілих білих щурах-самцях масою 60-80 г. Усіх тварин поділили на 4 групи: 1-ша - контроль (n=8); 2-га - щури, яким моделювали пасивне тютюнокуріння $(\mathrm{n}=8)$; 3-тя щури, яким вводили натрій глутамат $(n=8)$; 4-та - щури, яким моделювали пасивне тютюнокуріння на тлі введення натрій глутамату $(\mathrm{n}=8)$.

Вплив тютюнового диму (пасивне тютюнокуріння) моделювали шляхом поміщення щурів у спеціально сконструйовану камеру з оргскла об'ємом 30 л, що дозволило обкурювати тварин у вільній поведінці. Задимлення проводили, спалюючи 2 сигарети "Прима срібна (червона)" (смоли - 10 мг/сиг., нікотин - 0,8 мг/сиг.). У камері одночасно перебували 4 тварини. Піддослідні щури проходили процедуру пасивного тютюнокуріння 2 рази на добу по 30 хв. Після закінчення кожного 30-хвилинного сеансу тварин витягали з камери і поміщали в стандартну клітку віварію. Тривалість експерименту становила 30 днів $[11,12]$.

Тваринам 3-ї дослідної групи протягом 30-ти днів внутрішньошлунково вводили натрій глутамат у дозі 30 мг/кг, розчинений у 0,5 мл дистильованої води кімнатної температури [13]. Щурам 4-ї дослідної групи моделювали пасивне тютюнокуріння і вводили натрій глутамат протягом 30-ти днів. Контролем була група інтактних тварин.

Усі маніпуляції проводили 3 дотриманням принципів біоетики відповідно до положення Європейської конвенції про захист хребетних тварин, що використовуються для дослідних та інших наукових цілей (European convention for the protection of vertebrate animals used for expe- rimental and other scientific purposes, Страсбург, 1986), Закону України "Про захист тварин від жорстокого поводження" (від 15.12.2009 р. № 1759-VI) та Директиви Європейського Союзу 2010/10/63 EU щодо експериментів на тваринах.

Загальну протеолітичну активність сироватки крові визначали, використовуючи азосубстрати (азоальбумін, азоказеїн та азоколаген) фрірми "Simko Ltd" (Україна) відповідно до інструкції виробника. Принцип методу полягає в тому, що при інкубації протеїнових азосполук за присутності активаторів та інгібіторів протеолізу, які містяться у тканинах, відбувається лізис азоальбуміну (розпад низькомолекулярних протеїнів), азоказеїну (розпад високомолекулярних протеїнів) та азоколагену (колагеноліз), інтенсивність якого оцінювали за ступенем забарвлення інкубаційного середовища на спектрофротометрі СФ-46 при довжині хвилі 440 нм.

Статистичну обробку цифррових даних здійснювали за допомогою програмного забезпечення Excel (Microsoft, США) і STATISTICA 6.0 (Statsoft, США). Зважаючи на непараметричний розподіл кількісних характеристик, дані наводили у вигляді медіани і квартилів (нижнього та верхнього) - Me (Lq; Uq). Порівняльний аналіз 4-х підгруп здійснювали з використанням непараметричного критерію Краскела - Уолліса. Отримавши його вірогідні значення $(p<0,05)$, подальше попарне порівняння груп проводили із застосуванням критерію Манна - Уїтні 3 урахуванням поправки Бонфрерроні при оцінюванні значень р.

РЕЗУЛЬТАТИ Й ОБГОВОРЕННЯ. АНаЛіЗ результатів дослідження впливу тютюнового диму та натрій глутамату (табл. 1) показав, що у статевозрілих самців за умови пасивного тютюнокуріння протеолітична активність сироватки крові збільшувалась, що підтверджувалося вірогідним підвищенням лізису азоальбуміну, азоказеїну та азоколу. Так, лізис азоальбуміну зріс на 59,8 \% ( $\mathrm{p=0,002),} \mathrm{лізис} \mathrm{азоказеїну} \mathrm{-} \mathrm{на}$ $38,3 \%$ ( $<<0,001)$, лізис азоколу - на 32,6\% $(p=0,005)$ відносно контрольної групи.

Пасивне тютюнокуріння на тлі застосування натрій глутамату супроводжувалося більш вираженим підвищенням протеолітичної активності сироватки крові. Так, лізис азоальбуміну зріс на 97,3\% (p<0,001), лізис азоказеїну - на 61,7\% $(p<0,001)$, лізис азоколу - на 52,5\% $(p<0,001)$ відносно контрольної групи. Проте при зіставленні показників протеолітичної активності сироватки крові за умови пасивного тютюнокуріння та поєднаної дії тютюнового диму і натрій глутамату в статевозрілих щурів вірогідних відмінностей не виявлено. При цьому ізольоване 
Таблиця 1 - Вплив тютюнового диму і натрій глутамату на показники протеолітичної активності сироватки крові статевозрілих щурів

\begin{tabular}{|c|c|c|c|c|}
\hline \multirow{3}{*}{$\begin{array}{c}\text { Показник } \\
\text { (Mean } \pm \text { SD) }\end{array}$} & \multicolumn{4}{|c|}{ Група тварин } \\
\hline & 1-ша & 2-га & 3-тя & 4-та \\
\hline & контроль & $\begin{array}{c}\text { пасивне } \\
\text { тютюнокуріння }\end{array}$ & $\begin{array}{l}\text { натрій } \\
\text { глутамат }\end{array}$ & $\begin{array}{c}\text { пасивне тютюнокуріння+ } \\
\text { натрій глутамат }\end{array}$ \\
\hline $\begin{array}{l}\text { Лізис азоальбуміну, } \\
\mathrm{E}_{440} / \mathrm{M} / \text { год }\end{array}$ & $\begin{array}{c}2,24 \\
(2,17 ; 2,61)\end{array}$ & $\begin{array}{c}3,58 \\
(3,24 ; 3,73) \\
p_{1-2}=0,002^{\star}\end{array}$ & $\begin{array}{c}2,73 \\
(2,62 ; 3,13) \\
p_{1-3}<0,05 \\
p_{2-3}=0,012\end{array}$ & $\begin{array}{c}4,42 \\
(4,07 ; 4,86) \\
\mathrm{p}_{1-4}<0,001^{*} \\
\mathrm{p}_{2-4}=0,012 \\
\mathrm{p}_{3-4}=0,001^{*}\end{array}$ \\
\hline \multicolumn{5}{|c|}{ Критерій Краскела - Уолліса, p (H=24,34; p<0,001*) } \\
\hline $\begin{array}{l}\text { Лізис азоказеїну, } \\
\mathrm{E}_{440} / \mathrm{M} / \text { /год }\end{array}$ & $\begin{array}{c}2,27 \\
(2,19 ; 2,34)\end{array}$ & $\begin{array}{c}3,14 \\
(2,73 ; 3,42) \\
\mathrm{p}_{1-2}<0,001^{*}\end{array}$ & $\begin{array}{c}2,17 \\
(2,07 ; 2,61) \\
\mathrm{p}_{1-3}=0,018 \\
\mathrm{p}_{2-3}=0,004^{\star}\end{array}$ & $\begin{array}{c}3,67 \\
(3,31 ; 4,24) \\
\mathrm{p}_{1-4}<0,001^{*} \\
\mathrm{p}_{2-4}=0,018 \\
\mathrm{p}_{3-4}=0,001^{*}\end{array}$ \\
\hline \multicolumn{5}{|c|}{ Критерій Краскела - Уолліса, p (H=22,90; p<0,001*) } \\
\hline $\begin{array}{l}\text { Лізис азоколу, } \\
\mathrm{E}_{440} / \mathrm{M} / \text { год }\end{array}$ & $\begin{array}{c}1,41 \\
(1,17 ; 1,58)\end{array}$ & $\begin{array}{c}1,87 \\
(1,71 ; 1,96) \\
\mathrm{p}_{1-2}=0,005^{\star}\end{array}$ & $\begin{array}{c}1,75 \\
(1,39 ; 1,95) \\
p_{1-3}=0,046 \\
p_{2-3}<0,05\end{array}$ & $\begin{array}{c}2,15 \\
(1,79 ; 2,46) \\
p_{1-4}<0,001^{*} \\
p_{2-4}>0,05 \\
p_{3-4}=0,041\end{array}$ \\
\hline
\end{tabular}

Примітки. Тут і в таблиці 2:

1. $\mathrm{p}_{1-2}, \mathrm{p}_{1-3}, \mathrm{p}_{1-4}$ - вірогідність відмінностей між контрольною та дослідними групами; $\mathrm{p}_{2-3}, \mathrm{p}_{2-4}-$ вірогідність відмінностей між 2-ю, 3-ю і 4-ю групами; $p_{3-4}$ - вірогідність відмінностей між 3-ю і 4-ю групами.

2. Рівень вірогідності при попарному порівнянні груп для критерію Манна - Уїтні згідно з поправкою Бонферроні $\mathrm{p}<0,008$.

3. * - статистично значущі результати.

введення натрій глутамату не зумовило вірогідних відмінностей у лізисі азоальбуміну, азоказеїну та азоколу відносно контрольної групи.

У статевонезрілих щурів за умови пасивного тютюнокуріння лізис азоальбуміну вірогідно зріс на $62,1 \%$ ( $<<0,001)$, лізис азоказеїну - на 46,4 \% $(p<0,001)$, лізис азоколу - на 43,3 \% ( $<<0,001)$ відносно контрольної групи (табл. 2).

Пасивне тютюнокуріння на тлі застосування натрій глутамату супроводжувалося більш вираженим підвищенням протеолітичної активності сироватки крові. Так, лізис азоальбуміну зріс у 2,3 раза ( $p<0,001)$, лізис азоказеїну - на 99,7 \% ( $<<0,001)$, лізис азоколу - на 65,2\% $(p<0,001)$ відносно контрольної групи. При зіставленні показників протеолітичної активності сироватки крові за умови пасивного тютюнокуріння та поєднаної дії тютюнового диму і натрій глутамату в статевонезрілих щурів вірогідні відмінності виявлено щодо лізису азоальбуміну, що перевищував дані при ізольованому впливі тютюнового диму на 40,9 \% (p=0,002), та відносно лізису азоказеїну, який був більший, ніж за ізольованого впливу тютюнового диму, на 36,5% (p=0,003). Вірогідних відмінностей при зіставленні лізису азоколу за умови пасивного тютюнокуріння та поєднаної дії тютюнового диму і натрій глутамату не виявлено. При цьому ізольоване введення натрій глутамату зумовило вірогідні відмінності лише в лізисі азоальбуміну відносно контрольної групи (збільшення на 22,9 \%, p=0,002).

У віковому аспекті інтенсивність змін лізису азоальбуміну в сироватці крові статевонезрілих тварин практично не відрізнялася від показників статевозрілих щурів при ізольованій дії досліджуваних чинників, проте на 31 \% перевищувала показники статевозрілих самців за умови пасивного тютюнокуріння на тлі застосування натрій глутамату. Інтенсивність змін лізису азоказеїну в сироватці крові статевонезрілих тварин перевищувала показники статевозрілих самців: за умови пасивного тютюнокуріння - на 8,1 \%, при тривалому введенні натрій глутамату - на $18,1 \%$, за пасивного тютюнокуріння на тлі натрій глутамату - на 38,0 \% відповідно. Інтенсивність змін лізису азоколу в сироватці крові статевонезрілих щурів перевищувала показники статевозрілих самців: за умови пасивного тютюнокуріння - на 10,7 \%, при пасивному тютюнокурінні на тлі натрій глутамату - на 12,7 \% відповідно. За умови тривалого введення натрій глутамату інтенсивність змін лізису азоколу в сироватці крові статевонезрілих тварин практично не відрізнялася від показників статевозрілих щурів.

Протеолітичні ензими володіють високою біологічною активністю та беруть участь у регу- 
Таблиця 2 - Вплив тютюнового диму і натрій глутамату на показники протеолітичної активності сироватки крові статевонезрілих щурів

\begin{tabular}{|c|c|c|c|c|}
\hline \multirow{3}{*}{$\begin{array}{c}\text { Показник } \\
\text { (Mean } \pm \text { SD) }\end{array}$} & \multicolumn{4}{|c|}{ Г Група тварин } \\
\hline & 1-ша & 2-га & 3-тя & 4-та \\
\hline & контроль & $\begin{array}{c}\text { пасивне } \\
\text { тютюнокуріння }\end{array}$ & $\begin{array}{l}\text { натрій } \\
\text { глутамат }\end{array}$ & $\begin{array}{c}\text { пасивне тютюнокуріння+ } \\
\text { натрій глутамат }\end{array}$ \\
\hline $\begin{array}{l}\text { Лізис азоальбуміну, } \\
\mathrm{E}_{440} / \mathrm{M} / / \text { год }\end{array}$ & $\begin{array}{c}3,14 \\
(2,73 ; 3,42)\end{array}$ & $\begin{array}{c}5,09 \\
(4,79 ; 5,57) \\
\mathrm{p}_{1-2}<0,001^{*}\end{array}$ & $\begin{array}{c}3,86 \\
(3,50 ; 4,44) \\
p_{1-3}=0,002^{*} \\
p_{2-3}=0,002^{*}\end{array}$ & $\begin{array}{c}7,17 \\
(6,49 ; 7,80) \\
\mathrm{p}_{1-4}<0,001^{*} \\
\mathrm{p}_{2-4}=0,002^{\star} \\
\mathrm{p}_{3-4}<0,001^{*}\end{array}$ \\
\hline \multicolumn{5}{|c|}{ Критерій Краскела - Уолліса, $\mathrm{p}\left(\mathrm{H}=26,28 ; \mathrm{p}<0,001^{\star}\right)$} \\
\hline $\begin{array}{l}\text { Лізис азоказеїну, } \\
\mathrm{E}_{440} / \mathrm{M} / \text { год }\end{array}$ & $\begin{array}{c}3,58 \\
(3,24 ; 3,73)\end{array}$ & $\begin{array}{c}5,24 \\
(4,83 ; 5,89) \\
p_{1-2}<0,001^{*}\end{array}$ & $\begin{array}{c}4,07 \\
(3,75 ; 4,47) \\
\mathrm{p}_{1-3}=0,024 \\
\mathrm{p}_{2-3}=0,001^{\star}\end{array}$ & $\begin{array}{c}7,15 \\
(6,23 ; 7,30) \\
\mathrm{p}_{1-4}<0,001^{*} \\
\mathrm{p}_{2-4}=0,003^{\star} \\
\mathrm{p}_{3-4}<0,001^{*}\end{array}$ \\
\hline \multicolumn{5}{|c|}{ Критерій Краскела - Уолліса, $\mathrm{p}\left(\mathrm{H}=26,60 ; \mathrm{p}<0,001^{\star}\right)$} \\
\hline $\begin{array}{l}\text { Лізис азоколу, } \\
E_{440} / \mathrm{m} / \text { год }\end{array}$ & $\begin{array}{c}2,01 \\
(1,96 ; 2,05)\end{array}$ & $\begin{array}{c}2,88 \\
(2,56 ; 3,11) \\
\mathrm{p}_{1-2}<0,001^{*}\end{array}$ & $\begin{array}{c}2,38 \\
(2,13 ; 2,53) \\
p_{1-3}=0,010 \\
p_{2-3}=0,012\end{array}$ & $\begin{array}{c}3,32 \\
(2,96 ; 3,50) \\
p_{1-4}<0,001^{*} \\
p_{2-4}>0,05 \\
p_{3-4}=0,001^{*}\end{array}$ \\
\hline
\end{tabular}

ляції різних процесів, зокрема в реалізації імунної відповіді, згортанні крові, обміні речовин, підтриманні гомеостазу, запалення, травлення. Вони не лише здійснюють неспециорічний розпад протеїнових молекул, але і контролюють реакції загального та обмеженого протеолізу. За сучасними уявленнями, власне протеолітичні ензими підтримують рівновагу між загибеллю і деградацією клітин та їх відновленням [14, 15].

За умови пасивного тютюнокуріння в сироватці крові статевозрілих щурів збільшується кількість продуктів розпаду азоальбуміну, азоказеїну та азоколагену, що свідчить про підвищену деградацію як високомолекулярних, так і низькомолекулярнихпротеїнів та колагену. Підвищена деградація протеїнів, імовірно, пов'язана 3 їх окиснювальною модифрікацією, адже протеази "атакують" такі протеїни набагато легше, ніж немодифріковані [16]. Механізм протеолізу включає 2 етапи: (1) початкове окиснення протеїнів оксидантами, що містяться в тютюновому димі, з подальшим (2) швидким протеолітичним руйнуванням окиснених протеїнів протеазами. І. Ю. Сопова досліджувала зв'язок між інтенсивністю накопичення окисномодифікованих протеїнів і станом системи протеолізу в базальних ядрах мозку щурів після епізоду гострої гіпобаричної гіпоксії. Показано, що під дією гострої гіпоксії в базальних ядрах посилюються процеси пероксидації протеїнів паралельно зі збільшенням активності протеолізу. Акумуляцію окиснених протеїнів розглядають як один із фракторів, що впливають на активність протеаз [17].
Механізми тютюніндукованої окиснювальної модифікації протеїнів насамперед пов'язані 3 тим, що тютюновий дим містить речовини, які безпосередньо $є$ джерелом АФО (супероксиданіон-радикал, гідроген пероксид, гідроксильний радикал). Загалом, за даними D. G. Yanbaeva та ін., тютюновий дим містить $10^{17}$ молекул оксидантів на один вдих [18]. К. Panda та ін. встановили окиснювальну модифрікацію протеїнів (підвищення карбонільних похідних і бітирозину та зниження SH-груп) і виражений протеоліз мікросомальних протеїнів серця та легень in vitro [19] за умови впливу тютюнового диму. J. F. Greilberger та ін. визначали вміст карбонільних похідних протеїнів у плазмі крові курців та осіб, які не курять, імунофрерментним методом. Вони встановили вірогідне переважання вмісту карбонільних похідних протеїнів у плазмі крові

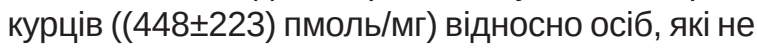

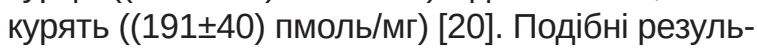
тати отримали й інші дослідники [21].

Крім того, індукована тютюновим димом активація запальних клітин сприяє підвищенню продукування оксидантів у тканинах [22]. Активовані запальні клітини індукують та активують ряд ензимів, таких, як синтаза нітроген (II) оксиду, мієлопероксидаза, НАДФН-оксидаза, пероксидаза. Ці ензими продукують велику кількість вільних радикалів та оксидантів (супероксиданіон-радикал, нітроген (II) оксид, гідроген пероксид та гіпохлоритну кислоту, що є нестійкою та відразу розкладається на $\mathrm{HCl}$ і атомарний оксиген, який є дуже сильним окисником та в 
подальшому генерує утворення пероксинітриту $\left(\mathrm{ONOO}^{-}\right)$) [20], що, у свою чергу, зумовлюють окиснювальну модифікацію протеїнів.

Цікаво, що поєднана дія тютюнового диму та натрій глутамату в статевозрілих щурів не зумовила вірогідних відмінностей у протеолітичній активності сироватки крові відносно ізольованої дії тютюнового диму. Щодо статевонезрілих тварин, то в них встановлено вірогідне переважання протеолітичної активності сироватки крові за умови пасивного тютюнокуріння на тлі застосування натрій глутамату відносно ізольованої дії тютюнового диму. Більш виражені зміни протеолітичної активності сироватки крові при поєднаній дії тютюнового диму та натрій глутамату, ймовірно, пов'язані з тим, що введення натрій глутамату підсилює прооксидний ефект тютюнового диму і, відповідно, сприяє більш вираженій окиснювальній модиорікації протеїнів. Прооксидний ефект натрій глутамату пов'язаний з гіперпродукуванням активних фрорм оксигену в дихальному ланцюзі мітохондрій. Крім того, зростання позаклітинного рівня глутамату посилює продукування гідроксильних радикалів. Дослідження А. Sharma показали підвищену активність $\alpha$-кетоглутарат-дегідрогенази за умови застосування натрій глутамату, що може активувати оксиген і утворення супероксиданіонрадикала та гідроген пероксиду [23].

ВИСНОВКИ. 1. За умови пасивного тютюнокуріння в сироватці крові статевозрілих щурів збільшується кількість продуктів розпаду азо- альбуміну, азоказеїну та азоколагену (на 59,8 \% $(p=0,002)$, на $38,3 \%(p<0,001)$, на $32,6 \%$ ( $p=0,005)$ відповідно), що свідчить про підвищену деградацію як високомолекулярних, так і низькомолекулярних протеїнів та колагену. Пасивне тютюнокуріння на тлі застосування натрій глутамату при цьому не зумовлює вірогідних змін відносно ізольованої дії тютюнового диму.

2. Інтенсивність деградації низькомолекулярних протеїнів і колагену в сироватці крові статевонезрілих щурів за умови пасивного тютюнокуріння перевищує аналогічні дані статевозрілих тварин на 8,1 та 10,7 \% відповідно. Пасивне тютюнокуріння на тлі застосування натрій глутамату при цьому зумовлює вірогідні зміни щодо лізису азоальбуміну, який перевищує дані за умови ізольованого впливу тютюнового диму на 40,9 \% ( $p=0,002)$, та відносно лізису азоказеїну, що перевищує дані при ізольованому впливі тютюнового диму на 36,5 \% (p=0,003). У віковому аспекті інтенсивність змін лізису азоальбуміну, азоказеїну й азоколу за умови пасивного тютюнокуріння на тлі введення натрій глутамату переважає на 31, 38 та 12,7 \% відповідно у статевонезрілих щурів.

3. Отримані результати свідчать про вищу інтенсивність протеолітичних процесів у статевонезрілих щурів порівняно зі статевозрілими. Імовірно, це зумовлено більшою інтенсивністю утворення вільних радикалів, меншою швидкістю їх знешкодження системою антиоксидантного захисту та утворенням більшої кількості окисномодифрікованих протеїнів.

\section{СПИСОК ЛІТЕРАТУРИ}

1. World Health Organization. Tobacco, WHO: Geneva, Switerland, 2019. - Access mode : https://www. who. int/news-room/fact-sheets/detail/tobacco

2. Pinkas J. The prevalence of tobacco and E-cigarette use in Poland: A 2019 Nationwide CrossSectional Survey / J. Pinkas, D. Kaleta, W. S. Zgliczy'nski // Int. J. Environ. Res. Public Health. - 2019. - No. 16. 4820. doi:10.3390/ijerph16234820.

3. Ещенко К. Н. Сердечно-сосудистая система и курение / К. Н. Ещенко, А. В. Жадан, Н. Ф. Шустваль // Ліки України. - 2013. - № 4. - С. 12-19.

4. Бабаев П. Н. Медицинская обращаемость и структура заболеваемости школьников, подвергающихся пассивному курению / П. Н. Бабаев // Общественное здоровье и здравоохранение. -2014. - № 1. C. $34-37$.

5. Горяев Д. В. Распространенность курения и риск утраты здоровья населением Красноярского края / Д. В. Горяев, И. В. Тихонова, Ф.В.Догадин // Гигиена и санитария. - 2015. - № 2.- С. 23-28.
6. Inchley J. Growing up unequal: gender and socioeconomic differences in young people's health and well-being. Health Behaviour in Schoolaged Children (HBSC) study: international report from the 2013/2014 survey / J. Inchley. - Copenhagen, WHO Regional Office for Europe, - 2016. - P. 276

7. Особенности распространения табакокурения среди школьников Украины / Н. С. Полька, О. В. Добрянская, Е. И. Турос [и др.] // Здоровье ребенка. 2016. - № 6 (74). - С. 27-29.

8. Волков І. І. Глутамат натрію як харчова добавка і її вплив на здоров'я / І. І. Волков, О. Ю. Косілова, Н. М. Кателевська // Scientific discoveries: projects, strategies and development: Collection of scientific papers " $\triangle$ 'ОГО $\Sigma$ " with Proceedings of the International Scientific and Practical Conference (Vol. 2), October 25, 2019. - Edinburgh, UK : European Scientific Platform, 2019. - C. 38-40.

9. Структурно-функціональні зміни в стінці товстого кишечника за умов введення глутамату натрію / 
О. О. Коленченко, Т. М. Фалаєєва, Т. В. Берегова, О. Г. Курик // Укр. журн. медицини, біології та спорту. 2017. - № 5 (7). - С. 39-43.

10. Бевзо В. В. Дослідження токсикодинаміки глутамату натрію на організм щурів за умов тривалого його введення / В. В. Бевзо // Клініч. та експерим. патологія. - 2016. - XV, № 2 (56), ч. 2. - С. 13-16.

11. Лизурчик Л. В. Влияние табачного дыма на содержание токсичных элементов в организме крыс / Л.В.Лизурчик, Е. В. Шейда // Вестн. ОГУ. - 2014. № 6 (167). - C. 71-74.

12. Exposure to secondhand smoke impairs fracture healing in rats / H. A. Santiago, A. Zamarioli, M. D. Soui sa Neto [et al.] // Clin. Orthop. Relat. Res. 2017. No. 475(3). - P. 894-902.

13. Влияние глипролинов на структурно-фрункциональное состояние слизистой оболочки желудка и массу тела крыс в условиях длительного введения глутамата натрия / Т. М. Фалалеева, Г. Е. Самонина, Т. В. Береговая [и др.] // Фізика живого. - 2010. - 18, № 1. - С. 154-159.

14. Кузьмак І. П. Зміни показників протеїназо-інгібіторної системи у щурів різних вікових періодів за умов гострого токсичного ураження блідою поганкою / І. П. Кузьмак, І. М. Кліщ // Мед. хімія. - 2011. - 13, № 3 (48). - C. 116-120.

15. Gogia S. Detection of plasma protease activity using microsphere-cytometry assays with $\mathrm{E}$. coli derived substrates: VWF Proteolysis by ADAMTS13 / S. Gogia, C. Y. Lo, S. Neelamegham // PLoS One. - 2015. No. 10 (5). - e0126556.

16. Дубинина Е. Е. Окислительная модисрикация протеинов, ее роль при патологических состояниях /

\section{REFERENCES}

1. World Health Organization. Tobacco; WHO: Geneva, Switerland, 2019; Retrieved from: https://www. who. int/news-room/fact-sheets/detail/tobacco

2. Pinkas, J., Kaleta, D., Zgliczy'nski, W.S. (2019). The prevalence of tobacco and E-cigarette use in Poland: A 2019 Nationwide Cross-Sectional Survey. Int. J. Environ. Res. Public Health, 16, 4820.

3. Yeshchenko, K.N., Zhadan, A.V., \& Shustval, N.F. (2013). Serdechno-sosudistaya sistema i kureniye [Circulatory system and smoking]. Liky Ukrainy - Medicines of Ukraine, 4 (170), 12-17 [in Russian].

4. Babayev, P.N. (2014). Meditsinskaya obrashchayemost i struktura zabolevayemosti shkolnikov, podvergayushchikhsya passivnomu kureniyu [Medical turnover and morbidity patterns of schoolchildren undergoing secondhand smoke]. Obshchestvennoye zdorovye $i$ zdravookhraneniye - Public Health and Healthcare, 1, 34-37 [in Russian].

5. Goryayev, D.V., Tikhonova, I.V., Goryayev, D.V., \& Dogadin, F.V. (2015). Rasprostranennost kureniya i risk utraty zdorovya naseleniyem Krasnoyarskogo kraya [The prevalence of smoking and the risk of loss of health by the population of the Krasnoyarsk region]. Gigiyena $i$ sanitariya - Hygiene and Sanitation, 2, 23-28 [in Russian].

6. Inchley, J. (2016). Growing up unequal: gender and socioeconomic differences in young people's health
Е. Е. Дубинина, А. В. Пустыгина // Укр. біохім. журн. 2008. -80 , № 6. - С. 5-18.

17. Сопова И. Ю. Связь между содержанием оксидативно модисрицированных белков и активностью протеолиза в базальных ядрах мозга крыс после острой гипоксии / И. Ю. Сопова // Нейрофизиология. - 2014. - 46, № 4. - С. 414-416.

18. Systemic effects of smoking / D. G. Yanbaeva, M. A. Dentener, E. C. Creutzberg [et al.] // Chest. -2007. No. 131 (5). - P. 1557-1566.

19. Cigarette smoke-induced protein oxidation and proteolysis is exclusively caused by its tar phase: prevention by vitamin C / K. Panda, R. Chattopadhyay, D. Chattopadhyay [et al.] // Toxicol. Lett. - 2001 . 123 (1). - P. 21-32.

20. Combination of 2-oxoglutarate/ascorbic acid/5hydroxymethyl-furfur-aldehyde/carnosine inhibits protein oxidation during radical exposure of cigarette smoke / J. F. Greilberger, R. Wintersteiger, O. Astrid [et al.] // Integr. Mol. Med. - 2018. - No. 5 (2). - P. 1-5.

21. Девина Е. А. Сравнительная оценка антиоксидантного действия ресвератрола и эпигаллокатехин галлата при окислительном стрессе, индуцированном сигаретным дымом в альвеолярных макрофрагах / Е. А. Девина, А. Д. Таганович // Лаб. діагностика. 2011. - № 1 (55). - С. 12-17.

22. Пишак В. П. Никотинзависимый оксидативный стресс и роль мелатонина / В. П. Пишак, М.И.Кривчанская, О. А. Громик // Укр. журн. клініч. та лаб. медицини. - 2013. - 8, № 4. - С. 17-19.

23. Sharma A. Monosodium glutamate-induced oxidative kidney damage and possible mechanisms: a mini-review / Sharma A. // Journal of Biomedical Science. - 2015. - No 22. - P. 93.

and well-being. Health Behaviour in Schoolaged Children (HBSC) study: international report from the 2013/2014 survey. Copenhagen, WHO Regional Office for Europe.

7. Polka, N.S., Dobryanskaya, O.V., Turos, Ye.I. Dardynskaya, I.V., \& Zeygler, D. (2016). Osobennosti rasprastraneniya tabakokureniya sredi shkolnikov Ukrainy [Features of the spread of smoking among schoolchildren of Ukraine]. Zdorovye rebenka - Child's Health, 6 (74), 27-29 [in Russian].

8. Volkov, I.I., Kosilova, O.Y., \& Katelevska, N.M. Hlutamat natriiu yak kharchova dobavka i yii vplyv na zdovia [Sodium glutamate as a dietary supplement and its health effects]. Scientific discoveries: projects, strategies and development: Collection of scientific papers "LOHOS" with Proceedings of the International Scientific and Practical Conference, 2), October 25, 2019. Edinburgh, UK: European Scientific Platform [in Ukrainian].

9. Kolenchenko, O.O., Falayeyeva, T.M., Berehova, T.V., \& Kuryk, O.H. (2017). Strukturno-funktsionalni zminy $v$ stintsi tovstoho kyshechnyka za umov vvedennia hlutamatu natriiu [Structural and functional changes in the wall of the large intestine under the conditions of administration of sodium glutamate]. Ukrainskyi zhurnal medytsyny, biolohii ta sportu Ukrainian Journal of Medicine, Biology and Sport, 5 (7), 39-43 [in Ukrainian]. 
10. Bevzo, V.V. (2016). Doslidzhennia toksykodynamikiv hlutamatu natriiu na tryvalist shchuriv dlia tryvaloho yoho vvedennia [Investigation of the toxicodynamics of glutamate sodium in rats under the condition of its long introduction]. Klinichna ta eksperymentalna patolohiia - Clinical and Experimental Pathology, XV, 2 (56), 2, 13-16 [in Ukrainian].

11. Lizurchik, L.V., \& Sheyda, E.V. (2014). Vliyanie tabachnogo dyma na soderzhaniye toksichnykh elementov $v$ organizme krys [Effect of tobacco smoke on the content of toxic elements in the body of rats]. Vestnik OGU - Journal of the Orenburg State University, 6 (167) 7174 [in Russian].

12. Santiago, H.A., Zamarioli, A., Sousa Neto, M.D., Volpon, J.B. (2017). Exposure to secondhand smoke impairs fracture healing in rats. Clin. Orthop. Relat. Res. 475 (3), 894-902.

13. Falaleeva, T.M., Samonina, H.Ye., Berehova,T.V., Dzyubenko, N.V., \& Andreeva, L.A. (2010). Vliyanye gliprolynov na strukturno-funktsyonalnoe sostoyanye slyzystoy obolochky zheludka i massa tela krys v usloviyakh dlitelnogo vvedenniya hlutamata natriya Fizyka zhyvoho - Physics of the Living, 18 (1), 154-159 [in Russian].

14. Kuzmak, I.P., Klishch, I.M. (2011). Zmineni rezultaty proteinazo-inhibitornoi systemy u shchuriv riznykh vikovykh periodiv za umovy hostroho toksychnoho urazhennia blodoiu pohankoiu [Changes in proteinaseinhibitory system indices in rats of different ages in acute toxic lesions with toadstool]. Medychna khimiia - Medical Chemistry, 13 (3), 116-120 [in Ukrainian].

15. Gogia, S., Lo, C.Y., \& Neelamegham, S. (2015) Detection of plasma protease activity using microspherecytometry assays with $\mathrm{E}$. coli derived substrates: VWF Proteolysis by ADAMTS13. PLoS One, 10 (5):e0126556.

16. Dubinina, E.E., \& Pustyhina, A.V. (2008) Okislitelnaya modifikatsiya proteinov, yeye rol pri patologicheskikh sostoyaniyakh [Oxidative modification of proteins, its role in pathological conditions]. Ukr. biokhim. Zhurn. - Ukrainian Biochemical Journal, 80 (6), 5-18 [in Russian].
17. Sopova, I.Yu. (2014). Svyaz mezhdu soderzhaniyem oksidativno modifitsirovannykh belkov i aktivnostyu proteoliza $v$ bazalnykh yadrakh mozga krys posle ostroy gipoksii [The relationship between the content of oxidatively modified proteins and the activity of proteolysis in the basal nuclei of rat brain after acute hypoxia]. Neyrofiziologiya - Neurophysiology, 46 (4), 414-416 [in Russian].

18. Yanbaeva, D.G., Dentener, M.A., Creutzberg, E.C., Wesseling, G., \& Wouters, E.F. (2007). Systemic effects of smoking. Chest., 131 (5), 1557-1566.

19. Panda, K., Chattopadhyay, R., Chattopadhyay, D., \& Chatterjee, I.B. (2001). Cigarette smoke-induced protein oxidation and proteolysis is exclusively caused by its tar phase: prevention by vitamin C. Toxicol. Lett., 123 (1), 21-32.

20. Greilberger, J.F., Wintersteiger, R., Astrid, O., Greilberger, M., \& Herwig, R. (2018). Combination of 2-oxoglutarate/ascorbic acid/5-hydroxymethyl-furfuraldehyde/carnosine inhibits protein oxidation during radical exposure of cigarette smoke. Integr. Mol. Med., 5 (2), 1-5.

21. Devina, E.A., \& Taganovich A.D. (2011). Sravnitelnaya otsenka antioksidantnogo deystviya resveratrola i epigallokatekhin gallata pri okislitelnom stresse, indutsirovannom sigaretnym dymon v alveolyarnykh makrofagakh [Comparative evaluation of the antioxidant effect of resveratrol and epigallocatechin gallate under oxidative stress induced by cigarette smoke in alveolar macrophages]. Lab. diagn. - Laboratory Diagnosis, 1 (55), 12-17 [in Russian].

22. Pyshak, V.P., Kryvchanska, M.I., \& Gromik, O.A. (2013). Nikotinzavisimyy oksidativnyy stress i rol melatonina [Nicotine-dependent oxidative stress and the role of melatonin]. Ukrainskyi zhurnal klinichnoi ta laboratornoi medytsyny - Ukrainian Journal of Clinical and Laboratory Medicine, 8 (4), 17-19 [in Russian].

23. Sharma, A. (2015). Monosodium glutamate-induced oxidative kidney damage and possible mechanisms: a mini-review. Journal of Biomedical Science. 22, 93.

Н. В. Гецько, И. Я. Криницкая ТЕРНОПОЛЬСКИЙ НАЦИОНАЛЬНЫЙ МЕДИЦИНСКИЙ УНИВЕРСИТЕТ ИМЕНИ И. Я. ГОРБАЧЕВСКОГО МОЗ УКРАИНЫ

\section{ИЗМЕНЕНИЯ ПОКАЗАТЕЛЕЙ ПРОТЕОЛИТИЧЕСКОЙ АКТИВНОСТИ СЫВОРОТКИ КРОВИ У КРЫС ПРИ ПАССИВНОМ ТАБАКОКУРЕНИИ НА ФОНЕ ДЛИТЕЛЬНОГО ВВЕДЕНИЯ НАТРИЙ ГЛУТАМАТА В ВОЗРАСТНОМ АСПЕКТЕ}

\section{Резюме}

Вступление. Табакокурение ежегодно убивает более 8 млн человек во всем мире, из них около 1,2 млн являются пассивными курильщиками. Характерный признак современных пищевых технологий использование пищевых добавок, которые не всегда безопасны для здоровья человека.

Цель исследования - изучить влияние пассивного табакокурения на фроне длительного введения натрий глутамата на показатели протеолитической активности сыворотки крови у крыс разного возраста.

Методы исследования. Опыты выполнены на 32-х беспородных половозрелых белых крысах-самцах массой 180-200 г и 32-х беспородных половонезрелых белых крысах-самцах массой 60-80 г. Всех животных разделили на 4 группы: 1-я - контроль; 2-я - крысы, которым моделировали пассивное табакокурение; 3-я - крысы, которым вводили натрий глутамат; 4-я - крысы, которым моделировали пассивное табакокурение на фроне введения натрий глутамата. Общую протеолитическую активность сыворотки 
крови определяли, используя азосубстраты (азоальбумин, азоказеин и азоколлаген) фрuрмы "Simko Ltd" (Украина) в соответствии с инструкцией производителя.

Результаты и обсуждение. При пассивном табакокурении в сыворотке крови половозрелых крыс увеличивалось количество продуктов распада азоальбумина, азоказеина и азоколлагена (на 59,8 \% ( $p=0,002)$, 38,3 \% ( $p$ <0,001), 32,6 \% (p=0,005) соответственно), что свидетельствовало о повышенной деградации как высокомолекулярных, так и низкомолекулярных протеинов и коллагена. Пассивное табакокурение на фоне применения натрий глутамата при этом не вызывало достоверных изменений относительно изолированного действия табачного дыма. В сыворотке крови половонезрелых крыс пассивное табакокурение на фроне применения натрий глутамата обусловливало достоверные изменения лизиса азоальбумина, который превышал данные в условиях изолированного влияния табачного дыма на 40,9 \% ( $p=0,002)$, и лизиса азоказеина, который превышал данные при изолированном влиянии табачного дыма на 36,5 \% (p=0,003). В возрастном аспекте интенсивность изменений лизиса азоальбумина, азоказеина и азокола при пассивном табакокурениии на фроне введения натрия глутамата преобладала на 31,38 и 12,7\% соответственно у половонезрелых крыс.

Выводы. Полученные результаты свидетельствуют о высшей интенсивности протеолитических процессов в крови половонезрелых крыс по сравнению с половозрелыми. Вероятно, это обусловлено высшей интенсивностью образования свободных радикалов, меньшей скоростью их обезвреживания и образованием большего количества окислительномодифицированных протеинов.

КЛЮЧЕВЫЕ СЛОВА: пассивное табакокурение; натрий глутамат; протеолитическая активность.

I. HORBACHEVSKY TERNOPIL NATIONAL MEDICAL UNIVERSITY

\section{THE CHANGES OF BLOOD SERUM PROTEOLYTIC ACTIVITY IN RATS WITH MODELED SECONDHAND TOBACCO SMOKING COMBINED WITH PROLONGED ADMINISTRATION OF MONOSODIUM GLUTAMATE IN THE AGE ASPECT}

\section{Summary}

Introduction. Every year tobacco smoking kills more that 8 million people all over the world; 1.2 of them are secondhand smokers. Meanwhile, the characteristic feature of modern food technologies is the usage of food supplements which are not always safe for human's health.

The aim of the study - to investigate the changes of proteolytic activity of blood serum in rats in case of passive tobacco smoking combined with prolonged administration of monosodium glutamate in the age aspect.

Research Methods. Experiments were held on 32 outbred mature white male-rats 180-200 g weight and 32 outbred immature white male-rats 60-80 g weight. Each group of animals was divided into four subgroups: I - control $(n=8) ; I I-$ rats with modeled secondhand tobacco smoking $(n=8) ; I I I-r a t s$, which were injected with monosodium glutamate ( $n=8) ;$ IV - rats with modeled secondhand tobacco smoking combined with the monosodium glutamate injection ( $n=8)$. General proteolytic activity of blood serum was identified by using azosubstrates (azoalbumine, azocasein, azocollagen) of the Simko Ltd. Firm (Ukraine), according to the manufacturer's instructions.

Results and Discussion. On the condition of secondhand tobacco smoking in mature rats' blood serum the number of decomposition products of azoalbumin, azocasein, azocollagen raises (on $59.8 \%$ ( $p=0,002$ ), on $38.3 \%$ $(p<0.001)$, on $32.6 \%(p=0.005)$ accordingly), that shows the increased degradation of both high molecular and low molecular proteins and collagen. Secondhand tobacco smoking on the background of MSG usage doesn't cause possible changes relatively isolated influence of tobacco smoke. Secondhand tobacco smoking on the background of MSG usage in immature rats' blood serum caused significant changes of azoalbumin lysis, which exceeds data on the condition of isolated influence of tobacco smoke on $40.9 \%(p=0.002)$ and azocasein lysis, which exceeds data on the condition of isolated influence of tobacco smoke on $36.5 \%(p=0.003)$. According to the age aspect, the intensity of changes of azoalbumin, azocasein and azocollagen lysis on the condition of secondhand tobacco smoking on the background of introduction of MSG prevails on 31.38 and $12.7 \%$ accordingly in immature rats.

Conclusion. The received results testify about higher intensity of proteolytic processes in immature rats' blood in comparison of mature animals. This is possibly caused by higher intensity of the formation of free radicals, lower speed of their neutralization and formation of greater number of modified oxidized proteins.

KEY WORDS: secondhand tobacco smoking; monosodium glutamate; proteolytic activity.

Адреса для листування: І. Я. Криницька, Тернопільський національний медичний університет імені І. Я. Горбачевського мОз України, майдан Волі, 1, Тернопіль, 46001, Україна, e-mail: krynytska@tdmu.edu.ua. 